\title{
Conquest and Theology
}

The Jesuits in Angola, $1548-1650$

\author{
John K. Thornton \\ Professor of History and African American Studies, Boston University \\ Non-resident fellow, W.E.B. DuBois Institute, Harvard University \\ jkthorn@bu.edu
}

\begin{abstract}
The Jesuits played a key role in the evangelization of the Portuguese colony of Angola and its surrounding Kimbundu-speaking neighbors when they came with the colonial mission of Paulo Dias de Novais in 1575. Their experience is an example of evangelization in a colonial setting in Africa, and contrasts with Jesuit approaches to conversion in the neighboring and independent Kingdom of Kongo. They drew heavily on previous experiences in the Kingdom of Kongo, which had itself become Christian a century earlier and pioneered a marriage between African religion and Christian spirituality. When Jesuits came to Kongo in 1548 they found an existing established church and added relatively little to it before they left following political disputes. When Dias de Novais came to found Angola, he initially was militarily dependent on Kongo's assistance and the Jesuits, too, were dependent on the Kongolese version of Christianity, which is clear in their choice of vocabulary in the Kimbundu catechism that they sponsored and oversaw in 1628. However, the colonial situation in Angola made the Jesuits more willing to accept the idea of conversion by the sword, and they were notably less tolerant of African religious inclusions in Angola than in Kongo. The contrast in the two approaches was particularly evident when the Jesuits reopened a mission in Kongo in 1619.
\end{abstract}

\section{Keywords}

Angola - Kingdom of Kongo - Jesuits - missionary work - evangelization catechisms - colonialism - Portugal

* The author holds a Ph.D. in African History and an M.I. in Political Science from the University of California, Los Angeles (UCLA). He is the author of several books, including the winner of the Herskovits Prize for 2008, Central Africans, Atlantic Creoles and the Foundation of the 
The Jesuit involvement in West Central Africa forms an interesting test on the nature of missionary work and conversion in colonial and non-colonial settings in the early modern world. In West Central Africa, they worked in the Kingdom of Kongo, which was not a European colony, and in the Kingdom of Ndongo in Angola they participated in the colonial conquest of the region by Portuguese armies. In my own earlier work on missionary activity in West Central Africa, I posited that when European missionaries arrived in an area over which they had no political control, they tended to operate with an "open" system of conversion, giving wide latitude to local beliefs and attempting relatively minor changes. By contrast, in areas where Europeans exerted more control, missionaries advanced a "closed" version of Christianity, suppressing or rooting out many indigenous traditions. ${ }^{1}$

The Jesuit case is instructive since their work in colonial Latin America seemed to fit the closed colonial model, while their work in Asia seemed to be a classic example of the open model, with the "Chinese Rites" or Roberto de Nobili's work in Malabar being prominent. The two different political settings of Kongo and Angola led, not surprisingly, to some differences in the way Jesuits dealt with the indigenous religious traditions in each African society, and the differences are all the more interesting as the two societies adjoined each other and their populations spoke very similar languages and followed broadly similar pre-Christian religious traditions. It would seem logical then, that contrasting Kongo's conversion with that of Ndongo, we might see the contrast between open and closed models.

In fact, however, there was not a strong contrast between Jesuit religious strategies in the two regions. This is not to say there were none. The Jesuits did exhibit variable degrees of tolerance toward religious practices which they deemed non-Christian, and specifically those that they denounced as manifestations of the devil. In Kongo, they were remarkably tolerant of these practices even while regarding them as unacceptable; in Ndongo, they tended to denounce them and take vigorous action to suppress them-perhaps a manifestation of the greater physical power they had from the Portuguese in a colonial state. Nevertheless, the stark differences between open and closed interpretations of local religion I predicted are not in evidence

Americas, 1580-1660 (Cambridge University Press, 2008), which he co-authored with Linda M. Heywood, and A Cultural History of the Atlantic World, 1250-1830 (Cambridge University Press, 2012).

1 John Thornton, "The Development of an African Catholic Church in the Kingdom of Kongo, 1491-1750," Journal of African History 25/2 (1977): 147-167. See also Thornton, A Cultural History of the Atlantic World (Cambridge: Cambridge University Press, 2012). 
upon closer inspection. The surprising similarities between the two missions can, however, be explained by other countervailing factors that set the African cases apart from Jesuit missions in other parts of the early modern world.

A contrast between the two societies was muted by the fact that the Jesuits encountered Kongo first, in 1548, and that Kongo subsequently participated in the conquest of Angola as a Portuguese ally during the crucial formative period of the new colony. As a result, the missions were closely linked, and the impact of this early conjunction and its continuation throughout the era of Angola's conquest was vital to the development of both. The missions remained linked even after Kongo and Portugal had a major falling out that led to war.

\section{The Jesuits in Kongo and Angola, 1548-1622}

The conversion of Kongo to Christianity was one of the more remarkable accomplishments of the early modern Catholic Church. Within a few years of contact with the Portuguese, following a brief exchange of people, King Nzinga a Nkuwu of Kongo was baptized in 1491 as João I. His son Afonso (1509-1542) then established the church in the kingdom and created an educational network that trained the local nobility in Christian religious concepts, financing its operations and keeping it firmly under his control. During his reign, locally educated Kongolese elites carried the faith to literally every corner of his domains, so that when he died in 1542 it could rightfully be said that Kongo was a Christian country. Missionaries from Portugal played a remarkably small role in the propagation of Christianity, primarily being valued for their capacity to administer the sacraments, as this could only be done by ordained priests. Afonso expected even this dependency upon a foreign clergy to end, and Rome cooperated with him by elevating his son, Henrique, to the status of bishop. However, this did not produce a long lasting tradition of local ordination. In 1534, the Portuguese Crown claimed the right to appoint bishops for Kongo, and subsequently kept the numbers of priests low, while failing to promote significant numbers of Kongolese to holy orders. Thus Kongo was in the interesting position for most of its history as a Christian kingdom of hosting foreign priests primarily to administer the sacraments while keeping lay people in charge of Christian education throughout the realm. ${ }^{2}$

2 Thornton, "Afro-Christian Syncretism in Kingdom of Kongo," Journal of African History 54/1 (2013): 53-77. 
The Jesuits became involved in Kongo shortly after Afonso's death, with a mission that began in 1548. Afonso's successor Diogo I (1545-61) sent a Kongolese man of whole or partial Portuguese descent named Diogo Gomes, educated in Kongo's school system, as an ambassador to Portugal to request missionaries. Gomes contacted the Jesuits, accompanied them to Kongo, and then joined the order himself, taking the name Cornélio Gomes. He was probably responsible for the linguistic content of the first Kikongo catechism, published in 1556 (but no longer extant). The catechism likely included the linguistic equations between Christianity and local religion that would characterize Kongo's own interpretation of the faith. The mission ran into political difficulties with Diogo over matters of precedence and some local customs. It lasted only a few years. ${ }^{3}$

It was from contact with Kongo's southern neighbor of Ndongo that the Jesuits would come both as missionaries to non-Christians and as part of the Portuguese conquest, but their engagement was always tempered by contact with Kongo. Engagement with Ndongo began in 1560 when Portugal dispatched Paulo Dias de Novais and four Jesuits to the kingdom in response to King Ngola Kiluanje's request for missionaries. ${ }^{4}$ The mission did not make much progress and Dias de Novais soon returned to Portugal, leaving only the Jesuit Francisco de Gouveia to labor on in Ndongo, where he made some converts and established a small community of Christians. While Gouveia enjoyed considerable influence, he never managed to convert the king. ${ }^{5}$ When Dias de Novais returned to Angola in 1575, it was with an army, more Jesuits, and a charter "to subjugate and to conquer the Kingdom of Angola."

Kongo would play an important role in the initial conquest of Angola, for Dias de Novais's mission had begun largely because Kongo's king Álvaro I $(1568-87)$ agreed to allow Portugal to use his territory at Luanda as a base in compensation for the help Portugal had given him in quelling an uprising by a mysterious group of people called "Jagas." In addition to relying on Kongo for a base, Novais offered services to Kiluanje kia Ndambi, King of Ndongo, as mercenaries and assisted him in putting down rebellions of his own. But in 1579,

3 The best overall history of the region with a particular focus on missionary work and ecclesiastical history is Graziano Saccardo, Angola e Congo con la storia dell'antica missione dei Cappuccini, 3 vols. (Venice: Curia Provinciale dei Cappuccini, 1982-83).

4 Miguel Torres to Jesuit Superior General, 11 January 1560, in Monumenta Missionaria Africana, 15 vols., ed. António Brásio (Lisbon: Agência Geral do Ultramar, 1952-1988), 15:223. Henceforward $M M A$.

5 Francisco Rodrigues, "Historia da residencia da Companhia de Jesus em Angola," 1594, MMA 4:555-6; Garcia Simões to Provincial, 20 October 1575, MMA 3:141.

6 Carta da doação a Paulo Dias de Novais, 19 September 1571, MMA 3:36. 
upon hearing of Dias de Novais's charter and commission to conquer Angola, Ndongo's king expelled the Portuguese from his lands. ${ }^{7}$

In the aftermath of this disaster, the Portuguese fell back on their alliance with Kongo, but Kongo then retracted its official support of the Portuguese colony following the defeat of the Kongolese army by Ndongo in 1580 . However, Kongo continued to play an important role for some time both in Portuguese politics in Angola and in the way in which Christianity developed there. Even without official support from the king, many Kongolese noblemen privately helped the Portuguese. According to one report of 1588, some 4,000 Kongolese were serving in the Portuguese forces, and Andrew Battell, a captive Englishman serving in Portuguese forces around 160o, noted that it was a regular practice to bring a Kongolese nobleman to come with a troop of soldiers and to serve as an organizer for the new Christian community, as well as to be an intermediary between the surrendered Mbundu lord and the Portuguese assigned to collect tribute from him. ${ }^{8}$

In addition to receiving assistance from these noble allies, Dias de Novais also built support by taking in disgruntled local rulers from the fringe areas of Ndongo's control along the Kwanza and Bengo Rivers. The Jesuits successfully converted some of these local rulers to Christianity, conversion being a step toward their becoming Portuguese vassals, a change of status that was required by Portugal both for the allied and the conquered in the region. ${ }^{9}$ Baltazar Barreira, one of the leading Jesuits of the mission, described the baptism in 1581 of the first of these allied nobles, named Songa, as occurring in a large ceremony that was conducted by the Jesuits with great pomp and which included a number of Kongolese participants. In addition to an installation ceremony, there was also a ritualistic burning of country "idols." 10 These ceremonious conversions, which were made quickly and with considerable political expediency, characterized the advance of Portuguese rule in Angola.

If military aid from Kongo was important, the country played an even more substantial role in the Christian evangelization of Angola. The dependency of

$7 \quad$ Specifics on this period are found in Linda Heywood and John Thornton, Central Africans, Atlantic Creoles and the Foundation of the Americas, 1585-1665 (Cambridge: Cambridge University Press, 2007), 79-87.

$8 \quad$ Memorias de Diogo de Ferreira, 1588, MMA 4:491; Andrew Battell, The Strange Adventures of Andrew Battel in Angola, ed. E. G. Ravenstein (London: The Hakluyt Society, 1901), 64-5.

$9 \quad$ For a thorough legal study, see Beatrix Heintze, "Luso-African Feudalism in Angola? The Vassal Treaties of the 16th to the 18th Century," Revista Portuguesa de História 18 (1980): $111-31$.

10 Baltasar Barreira to Superior General of the Jesuits, 31 January 1582, MMA 15:269-78; Barreira to Sebastião de Morais, 31 January 1582, MMA 3:209-10. 
the Angola mission on Kongo was symbolically marked in 1596 when Rome elevated Kongo's capital of São Salvador as the seat of the bishop of Kongo and Angola, placing the nascent Angolan church under the nominal control of Kongo, where the bishop's cathedral was located. Kongo's ascendancy in religious matters was more symbolic than real, and Portugal claimed the right to appoint bishops of this new see.

The Jesuits were not entirely pleased with their dependence on the Kongo church, both in the core of the country and around Luanda. In 1592, Diogo da Costa described the Kongo church as being "very weak" and complained that "idiot priests" were responsible for baptisms given without instruction even to older children and adults. He even went so far as to describe their customs as "heathen."11 A good deal of missionary discontent in this vein must be measured against the Counter-Reformation Catholicism that the Jesuits brought, indeed even spearheaded in Europe itself, to Kongo. ${ }^{12}$ They opposed many elements of the existing religious life of even the most deeply Christian parts of Europe, and would certainly meet equally objectionable practices in Africa. However, they were convinced that thanks to the good will and obedience that the people of Kongo bore for the Christian religion, they easily would be able to teach the new ways of the church into which most Kongolese had been born. ${ }^{13}$

This joint alliance of the Jesuits with both the Kongo church and Kongo's military was sharply challenged in the early seventeenth century. Thanks to some key alliances, Portugal was able to recover the military initiative and made major conquests in Ndongo, driving the king from the capital and forcing him to come to terms. But in the process they also made incursions into Kongo and in 1622 launched a major, but unsuccessful, invasion. From that point onward, Kongo became the sworn enemy of Portugal and formal ecclesiastical relations were strained to a breaking point.

The new estrangement between Kongo and Angola meant that the Angolan church would not benefit from Kongo's long established network of schools and schoolmasters who led theological instruction in every corner of the country, just at the time when the Portuguese were conquering territory that was far from the area around Kongo's coastal land of Luanda. The Jesuits, along with Portuguese secular priests, were thus responsible for building a network themselves in Angola, and they never won the sort of general adherence to Christianity found in Kongo.

\footnotetext{
11 Diogo da Costa to Superior General, 20 March 1592, MMA 15:317.

12 See Thornton, "The Kingdom of Kongo and the Counter-Reformation," Social Sciences and Missions 26 (2013): 40-58.

13 Diogo da Costa to Jesuit Superior General, 20 March 1592, MMA 15:317.
} 


\section{Jesuit Efforts in Angola}

The Jesuits had been attempting for some time to form a cadre of teachers in Angola and to reach the country's large population. In a report of 1578 , Manuel Rodrigues spoke of making many converts and imagining that many more priests would be needed, but gave few specifics. ${ }^{14}$ In fact there were far too few Jesuits for them to take full responsibility for teaching the newly conquered in the way they wished, and much of that work fell to secular priests ordained by the bishop of São Salvador. The arrangement did not suit the Jesuits who did not put much trust in the educational acumen of the secular priests. The case of a long-standing ally, the ruler of Quitelle, who the highly active Jesuit priest Pedro Tavares visited in 1631 (nearly fifty years after the process began) is typical. When the Jesuit discovered a number of unacceptable religious practices in the ruler's land he offered to instruct him to become a Christian, to which the ruler replied proudly that he was already a Christian. Further investigation revealed that the ruler of Quitelle had been baptized by a secular priest who had pointedly allowed him to keep every element of the older religion. ${ }^{15}$

The Jesuits had strict standards for what elements of traditional religion they would tolerate, but they were also prepared to make almost as many compromises with indigenous beliefs as the Kongolese church had, when approaching the people of Ndongo and their northwestern neighbors, the Mbundu, who spoke a related but different language called Kimbundu. The Jesuits began deciding what was licit and what was not, and how elements of traditional religion could be reconciled with Christian theology, in fairly close conjunction with the existing Kongo church which controlled Luanda. When they arrived, they met a parish priest in Luanda who had come from Kongo, and Kongo lay teachers had been active in the kingdom as well. It is quite possible that the Kongo teachers in Luanda had been working in Mbundu lands as well, because the Jesuits recruited people to assist them who knew both Portuguese and Kimbundu from among this community of teachers, among them a bilingual person from São Tomé who had perhaps come through commercial contacts.

From a religious perspective, the practices of the Mbundu people and those of Kongo were very similar, just as their languages were closely related. ${ }^{16}$ The

\footnotetext{
14 Letter of Manuel Rodrigues, Évora, 29 November 1578, ARSI, Lus. 68, 262-62 v .

15 Pero Tavares to Jeronimo Vogado, 14 October 1631, MMA 8:65-6.

16 Duarte Lopes, Portuguese trader and emissary of Kongo to Rome, who had lived in both areas, thought that Kikongo and Kimbundu were as closely related as Spanish and
} 
Jesuits set to work on creating a catechism, but it took rather a long time to publish one. In a letter of 1581, Baltesar Afonso quoted the first line of the Lord's prayer in Kimbundu, "tatétu oé cála que úlo," indicating that they had made considerable progress in Kimbundu as a distinct language. ${ }^{17}$

The results of the first generation of missionary work in Angola are revealed in an examination of the Kimbundu catechism, composed probably in the 1620 by Father Francesco Pacconio just as the renewed Portuguese military establishment encroached on the heartlands of Ndongo. ${ }^{18}$ As it happened, the production of this work also coincided with a new catechism for Kongo, authored by the Jesuit Mateus Cardoso but informed linguistically by the best educated teachers in Kongo's lay teaching system. Comparing the two catechisms enables us to see the differences in Jesuit strategy which resulted as the two church structures diverged.

The Kimbundu catechism was probably the result of a generation of linguistic work by people who knew the religious system of Kongo, like the residents and teachers in Luanda, but also applied it to Kimbundu. An Mbundu priest named Dionisio da Faria Baretto, praised by the governor as being learned in theology, accompanied Paconio in his initial trip to evangelize the kingdom of Ndongo in $1625 .{ }^{19}$ The presence of a theologically sophisticated native speaker of Kimbundu in the missionary team may explain both the quality of the language in the text and its syncretic character. The fact that the final version of the text was later edited and prepared for publication in 1642 by António do Couto, a Jesuit who was born and raised in Kongo, may also explain the openness in the text toward syncretic conceptions of Christianity. ${ }^{20}$

Portuguese, or as some Italian dialects. See Filippo Pigafetta, Relatione del reame del Congo e delle circonvincine contrade (Rome: Bartolomeo Grassi, 1591).

17 Baltesar Afonso, quoted in letter of Baltesar Barreira, 31 January 1581, $M M A$ 15:274. The later Kimbundu catechism gave this same line somewhat differently as "Tat'etu üecâla co máulo." The history of Paconio's mastery of Kimbundu and preparation of the catechism is detailed in the introduction to François Bontinck and D. Ndembe Nsasi, Le Catéchisme Kikongo de 1624: réédition critique (Brussels: Académie Royale des Sciences d'Outre-Mer, 1978), 39-40. Unlike the Kikongo catechism, which was a translation of a well-known Portuguese catechism, the Kimbundu one seems to have been made especially for use in Angola.

19 On his biography, see Heintze, Fontes para a história de Angola do século XVII, 2 vols. (Wiesbaden: Steiner, 1985-88), 1:196, n. 4. For a fuller account of his actions see Fernão de Sousa, "Rellaçaõ de Dongo que foy a El Rey nosso senhor," 6 September 1625, in ibid., 198-9. António de Couto, SJ, ed., Gentio de Angola sufficiemente instruido nos mysterios de nossa sancta Fé, obra posthuma composta pello Padre Francisco Pacconio da Companhia de Jesu redusida ... pello Antonio de Couto... (Lisbon: 1642). 
That the Mbundu had similar spiritual conceptions to the Kongolese is demonstrated by the detailed description of religious practice in the Mbundu area made by Giovanni Antonio Cavazzi da Montecuccolo, composed between 1660 and $1665 .{ }^{21}$ The two catechisms reflect this similarity. The Kimbundu catechism uses the term "Nzambi" to mean God, related to the Kikongo term "Nzambi a Mpungu," and shows that the Jesuits were not afraid to identify their God with an Mbundu deity. ${ }^{22}$

Both religions had a strong attachment to the idea that the dead could influence the living and that it was appropriate to propitiate them with regular offerings at their graves. ${ }^{23}$ As a reflection of the attachment to ancestors, the Kikongo and Kimbundu texts use "atu atâtu" [three people] to refer to the Trinity, suggesting that even God himself (as well as the Holy Spirit and Jesus) were once living persons who had died and were now ancestors. ${ }^{24}$ However, the belief that the souls of the dead also remained to assist or sometimes to torment the living represented a problem that was only partially resolved by the recognition of an ancestral quality in God and the saints. The Kimbundu

21 Giovanni Antonio Cavazzi da Montecucclo, "Missione evangelica al Regno de Congo," in MSS Araldi (private collection of the Araldi family of Modena, Italy), vol. A, book 1, 72-101. My English translation and annotations are available at: http://www.bu.edu/afam/faculty/ john-thornton/cavazzi-missione-evangelica-2/. Despite the title, the manuscript is primarily about the Mbundu, and only peripherally about Kongo. Additional information on seventeenth-century Mbundu religion is supplied in an earlier text of Pero Tavares. See Tavares to Jeronimo Vogado, 14 October 1631, MMA 8:61-75; Manuel Ribeiro, "Carta da Missaõ que fizeraõ o P. Manoel Ribejro, e o Irmaõ Francisco Correa, mandados pelo P. Antonio de Souza Reitor, que entaõ era, do Colegio de Angola, anno de 1672 para o de 1673," 15 January 1674, MMA 13:248-74; and Giovanni Bellotti da Romano, "Avvertimenti salutevoli alli apostolici Missionari nè Regni del Congo, Angola e circunvinci," 1685, excerpted in Vittorio Maconi, "Magische Handlungen der Eingeborenen Nord-West Angolas," Kölner ethnologische Mitteilungen 4 (1965): 135-59.

22 There has not been a complete ethnography of the Mbundu done in modern times. Some important elements on conceptions of God in the 1920s were collected, but never published, by Amandus Johnson, in which God and "Kalunga," or the land of the dead, are connected, while "Suku," another term often employed in Central Africa, is mentioned as a guardian of the other world who admits people. See Archives of the University Museum, University of Pennsylvania, Amandus Johnson Papers, box 3, folder 10, notebooks, 1922, vol. 2, no pagination.

23 For an overview of religious views at the time, see Thornton, "Religious and Ceremonial Life in the Kongo and Mbundu Areas, 1500-1700," in Heywood, ed. Central Africans and Cultural Transformations in the American Diaspora (Cambridge: Cambridge University Press, 2002), 71-90.

24 Couto, Gentio, 1:10. In Kikongo the term was "antu atâtu." 
catechism did not specifically attack the idea of the ancestors any more than the Kikongo one did: both explained Christian ideas without attacking African ones. Nevertheless, missionaries sometimes reported on what they considered to be theologically unacceptable ideas from some of their baptized parishioners.

The two peoples approached divinity differently, at least insofar as that approach manifested itself in Christianity. In Kongo, the theologians of Afonso's court had used variants of the term "-kis"- signifying a transcendent spiritual force that might take named forms and inhabit charms - to translate words such as "holy" or "divinity." In the Kimbundu catechism, differently, forms of the more personal term "zambi," which referred to the name of a specific deity in the traditional religion, are used. ${ }^{25}$ For example, the persons of the Trinity were called "Nzambi Tata" [Father God], "Nzambi Mona" [Son God] and "Nzambi Spiritu Santo" [Holy Spirit God]. ${ }^{26}$ Interestingly, the abstract term "unzambi" was used to mean "divinity" in the catechism. ${ }^{27}$ Elsewhere in the catechism, the Jesuits used the term "jinzambi" (the plural form) to mean "gods" in a generic sense. ${ }^{28}$ At the same time, the Kimbundu catechism generally avoided the use of the term "holy," which the Kikongo text uses frequently through variants of the root "-kis," which connects directly to the Kikongo term for a transcendent spiritual force. In most cases, the Portuguese text of the catechism which bears such language was simply not translated, so that "this

25 On "-kis" and its variants in Kikongo, see Thornton, "Afro-Christian Synthesis," 71-75.

26 Couto, Gentio, 1:14. A description of the Trinity is worded in Kimbundu, "O mutu üariangue Tata, Nzambi, üa muchi ari Mona, Nzambi, üa muchi tatu Spirito Santo, Nzambipè,” and also in Portuguese, "a primeira que he Padre, he Deos, a seconda que he Filho, he Deos, a terceira que he Spirito Santo, he tambem Deos" [the first which is the Father is God, the second is the son, is God and the third which is the Holy Spirit, is also God]. Elsewhere, the term "Mona Nzambi" is used as a translation for "Verbo Divino" [Divine Word], and the Portuguese text's term for Jesus, "mona," means "son" in Kimbundu (2:7). Also, "Spirito Santo" is rendered in Kimbundu as "Nzambi Spirito Santo" (2:8), and the Portuguese "Iesu he o proprio nome que lhe deu o Padre eterno" [Jesus was the name which the Eternal Father gave him] is worded in Kimbundu, "Gina rîae Iesu Christo: Ieso o ndûco yae emuêne yamubi Nzambi Tata” (2:14).

27 Ibid., 2:12. "Unido a sua divinidade este corpo \& alma" [united his divinity with this body and soul] is rendered in Kimbundu as "uchi o mucûtu, ne muenho óu co Vnzambi üae" when describing the descent of the Holy Spirit in the Immaculate Conception. See ibid., 2:4.

28 Ibid., 3:4. In referring to God's decision to forbid the eating of the apple in the Garden of Eden, "na hora que comerdes deste pomo, sereis como Deoses" [at the time when they would eat the apple they would be like gods] is rendered in Kimbundu as "quiüa he muario quirima muquntuo ula Ginzambi." 
most holy name" [este sanctissimo nome] was simply rendered as "o ngin'eri" [this name.$^{29}$

An important difference between the Kikongo and Kimbundu catechisms is their attitude toward traditional African religion. While the Kikongo catechism makes no reference to anything relating to the traditional religion of Kongo, the Kimbundu catechism asks its users to renounce "idols" and "witchcraft." The terms used for each of these, "iteke" (the plural form) and "uwanga" [abstract form] are not used elsewhere in any context. ${ }^{30}$ However, the Kimbundu term for "witchcraft"-or using supernatural powers for harmful ends-as understood in the traditional religion was "wanga," and thus the two terms coincided in Europe and Africa.

The same was not true with "iteke," or "idols." In Kimbundu, "iteke" were substantial shrines to guardian spirits, to which traditionally a considerable cult was devoted, though the term "iteke" (singular "kiteke") generally refers only to the shrine and not the otherworldly being that it served, which was called a "kilunda."31 The Kimbundu catechism made no use of "kilunda" or its reflexes for anything spiritual, and so created no convergence. Interestingly enough, while in the Kingdom of Kongo the term for a similar shrine (including personal objects that were spiritually charged) was also "kiteke," the name of the spirit that charged it was "nkisi" (drawing on the root "-kis," referring to a transcendent spiritual force). In the Kikongo speaking but non-Christian Kingdom of Loango, the term for both the entity and the object it entered was "nkisi."32

The Mbundu territorial guardians were responsible for the general welfare of the locality, bringing sun, rain, bountiful harvests, and good luck to the people in their common endeavors. When Tavares wished to burn the kiteke of Golungo in 1631, the local people appealed to him not to, saying it was their "doctor and aid for their necessities, sun, rain, etc."33 The extirpation and replacement of such shrines was important to the Jesuits, using concepts of witchcraft as the justification, essentially charging that its spiritual agency was the result of the

\footnotetext{
29 Ibid., 2:14.

$30 \quad$ Ibid., 1:9. "Crer em um so Deos verdadeiro, ha de arrenegar dos Idolos de seus preceitos, de todo genero de feiteicerios" [believing in one sole true God is to renounce the idols and their precepts and all manner of witchcraft] is "chíquina mo Nzambi imoxi ei yaquîri, ucuatûna o Iteque, ne igilla, ne üanga üesse üesse.”

31 For the fullest account of these shrines and their theology, see "Missione evangelica," Cavazzi, MSS Araldi, vol. A, book 1.

32 Thornton, "Afro-Christian Syncretism," 71-73.

33 Tavares to Vogado, 14 October 1631, MMA 8:70. For a similar supplication made in 1673, see Ribeiro, "Carta," $M M A$ 13:267-8.
} 
devil's work. Tavares devoted a great deal of attention to attacking these shrines, and made a special trip just to seize and burn one at Golungo. ${ }^{34}$

In destroying the iteke, the Jesuits' aim was to replace the shrines, which were typically located in prominent places within Mbundu towns, with Christian crosses, and to encourage new festivals similar to those conducted at the older shrines at appropriate times. At times the popularity of the new shrines benefitted from a co-revelation, or the occurrence of a reported miracle that was religiously significance in multiple ways, for both the missionaries and their targets. For example, when Tavares visited Quionzo, the people there told him that before a "white man" had erected a cross on the public square, "there had been years in which not a drop of rain had fallen on the lands of the Soba, even though it fell on those of his neighbors," but that when the cross came, then it rained [...] so they paid the respect to the cross and he who had died on it for bringing them rain." ${ }^{35}$

If the specific nature of the kiteke was the subject of Jesuit criticism and even violent action, its religious nature continued to be respected by local Christians. The kilundas who were worshipped at the shrines gave their communities rules and taboos to follow as a means of ensuring their continued protection. The language of the catechism effectively transferred this idea to the otherworldly beings of the Christian cosmology. The term used for the taboos (precepts) observed by the "idols" [kijila], was also employed by the catechism in reference to divine laws and prohibitions. ${ }^{36}$ In a mid-seventeenthcentury revision of the catechism, it was even used to replace a more general term for law, "milongo," in the Ten Commandments. ${ }^{37}$ Since the concept of

34 Tavares to Vogado, 14 October 1631, $M M A$ 8:61, 69-75.

35 Ibid., 67.

36 Couto, Gentio, 1:8v. The Portuguese is worded, "A primeira crer o que nos manda crer. A segunda guardar o que nos mãde guardar." [The first is to believe that which he orders us believe. The second is to keep that which he orders us keep]. The Kimbundu is rendered, "O yuma yesselelè yatutúmine Nzambi mo ubîca üae; uyenda mo ngilla giàrino ngilla yariangue milonga imoxiya cuchi qüina; mo ngilla yassalla milonga mi ingui ya ouyaleuea." The use of "ngilla" (referring to a ritual prohibition) in this passage, especially coupled with terms like "ubîca," meaning power or lordship (also the root of slave "mubica") and "milonga" effectively Christianized the concept of taboo. Elsewhere, the same term is used when requiring Christians to renounce the "precepts of Idols," i.e. "Iteque, e ngilla" (1:9).

37 Antonio da Monteprandone, Gentilis Angollae fidei mysteriis lusitano olim idiomate per R. P. Antonium de Coucto Soc. Jesu Theologum, nuc autem Latino per Fr. Antonium Mariam Prandemontanum, Concionatorem Capucinum (Rome: 1661) 5. The text is a reedition of Couto's catechism, with an additional column in Latin, for use by the largely Italian 
keeping the rules given by "idols" was noted with disapproval by a number of seventeenth-century missionaries, the catechism's use of the term implies that the concept of divine rules was considered valid, but that a monopoly on defining and enforcing them belonged to the church. ${ }^{38}$

\section{Jesuit Attitudes toward Religious Practice in Kongo and Angola}

The Jesuits' attention to suppressing elements of indigenous religion in the Kimbundu catechism may well reflect the differences in the way the two regions were perceived. Kongo was already Christian, and devotion to the faith there was held to be high. In Angola, conversion was often linked to conquest, so that allies or the defeated accepted conversion as a matter of political expediency or necessity.

In Angola, the Jesuits were fierce advocates of war against the Mbundu to convert them by force. Their lengthy correspondence reads as much like the chronicle of conquest as the report of missionary activities, and they saw, early on, that conquest would be a crucial part of their idea of spreading the faith. Sometime between 1610 and 1617 , following a long period of war and evangelization an anonymous Jesuit wrote that it had proved impossible to introduce true Christianity anywhere in Angola except the areas around Luanda (which had been Kongo territory) and the forts that Portugal controlled directly. From this, he drew the conclusion that a complete conquest of Angola was necessary. To achieve it, he believed what was needed was "cruel war" to destroy everything, since Angolans "would only come to the faith when they had fear of the Portuguese muskets." 39

On the other hand, in 1619 the Jesuits opened a formal mission in Kongo, though there had been visits and reconnaissance before then. The approach to Kongo was very different from that in Angola. When Angolan governor João Correa de Sousa invaded Kongo in 1622 the Jesuits roundly denounced him, for "marching to war, not against a few heathens but Christians who are the vassals of the King of Congo, brother of arms of Your Majesty who has a See and a bishop in his court." 40

speaking Capuchin mission, but a comparison of the text of 1661 with that of 1642 shows a number of linguistic changes.

38 See especially “Missione evangelica," Cavazzi, MSS Araldi, vol. A, books 1-2.

39 Anonymous, "Informação sobre as missões q[ue] se podem fazer em Angola e outros Reinos vizinhos," n. d. (post 1610, pre 1617), ARSI, Lus. 55, 195-198

40 Jesuits to Lord Collector, 20 October 1623, MMA 15:512. 
The Jesuits' attitude toward Kongo was revealed when the Inquisition visited Angola in 1596. It did not concern itself with African religious practices, but focused on rounding up New Christians (descendants of Jews who had converted to Christianity in 1529) accused of practicing Judaism in secret or denouncing the church. Although there were occasional mentions of "fetishism," none of the denunciations were explicitly for practices associated with African religions. ${ }^{41}$ However, when the Inquisition returned later on to Angola, collecting testimony intermittently between 1626 and 1632 , it took on a more theological twist. In this round, African religious practices were denounced as witchcraft (fetishism) or idolatry, but with interesting regional distinctions. In Kongo, all the denunciators of what could be called religious crimes, such as idolatry, were themselves Kongolese, while Jesuit denunciations were aimed at the secular clergy serving in the country. In Angola, on the other hand, religious crimes were denounced by Jesuits, especially Tavares. ${ }^{42}$ Tavares favored the arrest of "idolators" he encountered in Angola, while in Kongo the Jesuit visitor simply thought reports of idolatry were relatively harmless, and could be easily resolved by more education. ${ }^{43}$ In the end, even theologically oriented Jesuits, who often reported on unacceptable ideas, and occasionally even debated people in areas that were supposed to be Christian, generally accepted what had developed in Angola as Christianity. ${ }^{4}$

Thus, despite the substantial differences in their political situations, missionaries both in Kongo and the Kimbundu-speaking areas of Angola developed Christian theologies that essentially incorporated large components of indigenous spirituality. These two syncretic systems could then potentially have been carried across the Atlantic, where so many Central Africans served as catechists, and also be translated into other African religious systems. The role of Kongolese clergy and lay catechists in developing a syncretic form of Christianity in conquered Angola may just as well have served the same purpose in the America of the slaves.

The conversion of Angolans had its reflection in the religion of slaves in Brazil. The same wave of Portuguese conquest and colonization that had led to the formation of Kimbundu Christianity also brought thousands of slaves to

41 Arquivo Nacional de Torre do Tombo (ANTT), Inquisition, Lisboa, Livro 877, "Visitições a Angola," $1596-97$.

42 ANTT Inquisition, Lisboa, Tribunal do Santo Oficio, maço 9, document 8, "Denunciações do reino do Congo e Angola," c.a.162o/c.a.1632, no pagination.

Ibid., "Denunciações, Lembramento de Miguel Afonso acerca das conpitas dos Moxicongos."

See especially Ribeiro's account, $M M A$ 13:258, 262. 
Brazil, and there in the most successful of the sixteenth-century captaincies, Bahia and Pernambuco, the Jesuits took the lead not only in converting the indigenous Brazilians but also the African slaves who came among them. In this, they employed the language of their early catechisms. Jesuits in Pernambuco, for example, studied Kimbundu and learned to read and even to compose in the language, as sixteenth-century sources reveal. Both Christian and traditional religious ideas and practices crossed the Atlantic with these slaves, as James Sweet's study of the Inquisition archives shows. ${ }^{45}$

The specific Central African variant of Christianity discussed here, which incorporated African concepts into Christian theology, very likely was at the root of later forms of Brazilian Christianity that have become world famous. In the late seventeenth century, West African spirituality was also incorporated into this tradition of Christianity. Investigating the processes of that tradition's development, both as consolidated by Jesuits and widely taught in both Africa and America, is an important task for the future in Jesuit studies.

45 James Sweet, Recreating Africa: Religion, Kinship and Culture in the Portuguese World, 1441-1770 (Chapel Hill: University of North Carolina Press, 2003). 